\title{
Vietnam and COVID-19: More Mark (Zuckerberg) than Marx
}

Edition 4, 2020

Associate Professor Adam Fforde

DOI: 10.37839/MAR2652-550X4.13

Vietnam's success (so far) in responding to COVID-19 reflects both government and social resilience:

- Politically and practically effective official responses, led from the top, with adaptive coherence of government actions at all levels; and

- Popular criticism and acceptance, and so authentic authorisation of those responses.

Vietnam is widely seen as ruled by a strong authoritarian regime. But there is much evidence that its population is increasingly unruly, does not, as a matter of course, see the regime as legitimate, and that the Vietnamese state does not possess, as a matter of course, a high degree of internal discipline. Corruption is widespread and Party members cannot be investigated by state bodies without the approval of the appropriate Party body.

Authority is a relationship, and, facing COVID-19, the Vietnamese government 'stepped up' at what appears to be all levels, and have been supported for doing so (and criticised when they did not). People made up their own minds, which may reflect more the influence of Mark Zuckerberg-through open discussion on platforms such as Facebook-than Karl Marx. The Vietnamese people obey when they see the point. 


\section{Vietnam's excellent COVID-19 numbers (so}

\section{far)}

A range of reports tell us that the Vietnamese have done very well in coping with COVID-19. There have been almost no deaths, and very low reported infections.

As of late October, Vietnam had recorded approximately 1,170 confirmed cases and 35 deaths, in a population of 95.5 million. Figures show daily new cases on a sevenday moving average peaking first at 12 on April 2, then at 35 on August 7 and some signs of a third spike in September with 17 cases on September 29. Total deaths reached 35 on September 3 and there have been none since (as of October 29). The first deaths were on July 31. So far, the Vietnamese have not seen congestion in intensive care units and the brutal issues of triage.

Testing in Vietnam has been done well and extensively, drawing on a powerful system founded on 'event-based' surveillance, allowing a wide range of people to input data on public health events to the central database. Locally-made test kits were widely available, with high levels of tests per confirmed case (a number driven by the low rates of infection).

Contact tracing is relatively very high and thorough, based on risk of infection rather than exhibition of symptoms, which would seem to by-pass the problem of asymptomatic infections. Regarding isolations, over 200,000 people were put in quarantine facilities. Restrictions on the population's movements were used, including a nationwide lockdown from April 1.

This narrative attributes success to cause-effect logics that are clearly understandable, even if they do not likely robustly link to the complexities of epidemiologists' models. There can be a strong tendency in Vietnam for there to be 'local logics', for mentality ('tư duy') can be and often is expected to vary over time and between places, and this is often a normal part of Vietnamese policy narratives. 
This is reminiscent of the 'task-based' methods of the US Marine Corps, according to James Mattis.

\section{The formal policy response is credible}

There is a lot of information, which is suggestive. There are no suggestions of 'coverups' and manipulation of data to serve political ends. Vietnamese are generally sceptical (often highly sceptical) about their officials' statements. But they have Facebook and 'attitude', and the state provides lots of information on policy, COVID-19 events and so on. This pushes for credibility.

There are many data sources, as both local and central state decisions are discussed and referenced in the mass media. I have learnt to 'go to the source' and use the official government website. This source deserves research of itself. It is free, and contains laws and directives of the Prime Minister, Ministries and local governments (provinces/centrally-governed cities) - there are 63, in a country with a total population near 100 million, containing the two largest cities of Hanoi and Ho Chi Minh city with about eight million each. The entire database is massive, containing thousands of documents going back to 1945. It is easy to search, and fast.

Searches on COVID-19 and related terms give perhaps 1,000 documents 'around now', from Ministries, the Prime Minister and province and cities. These show anybody who cares to look interesting things about the formal policy history and its rhetoric. The character of the sources convinces a researcher like me that they are genuine. We can see the state talking to itself and its people. For example, we can see (by listing the documents in temporal order) what the initial sequence was. The first documents were issued (that is, by date of signature rather than date of gazetting in the official Công Báo) by the Ministry of Health on January 16, 17 and 21,2020 . These are clear and professional. But then the central state acts, under the Premier's remit, and this gets interesting, and powerful.

The first 'major state act' was on January 23, from the Premier (Nguyẽn Xuân Phúc), 
there was a 'Công điện'. On January 24, we find the first local government responses from Hải Dương and Ninh Thuận provinces (about 2.5 million and 600,000 people respectively). They are the first to issue plans, and not to a single template, suggesting that we are headed for a process of a central vision, but local implementation. In other words, that the response was not going to be blueprint driven.

This stance is then driven home by 'the big alarm'. On January 28, this alarm comes with the Premier's first 'Directive' on anti-COVID measures. This is a fascinating and forceful document: "Ministries, branches and localities must not be subjective ("chủ quan") ... and must see their work ... as 'fighting an enemy' ("chống giặc"). That is, in my reading, a statement to officials that they 'don't mess up' and 'respond to real local needs' rhetoric that is coming from the Premier (not the Party). The tone is tough and deadly serious. The attack on 'subjectivity' can be read as 'take the overall task as key but adapt to real local conditions'. This fits Vietnamese tendencies to focus on local conditions and local meaning construction, or 'mentality' ('tu' duy'). The war rhetoric is familiar from before 1954, before 1975 and 1978/79. The Premier's style cannot, though, in my view, be seen as 'martial'. I read the January 28 Directive as inclusive, aimed at general population and state officials. At this stage, given the massive amount of information and problems in gauging cause and effect, I leave the analysis at this level. My view of what has happened so far is that it shows, to us and the Vietnamese, what can be done when officials 'step up' with popular support that is based upon active criticism and a government willing and ready to listen to it-even in Vietnam, much to many peoples' surprise.

Many of these documents require that officials listen to and report on public opinion. There is a large security apparat. So, 'would the people treat official pronouncements seriously' and 'would officials 'step up'? Would compliance be forced, or would there be self-policing and popular evaluation of policy and officials? 


\section{The public response to COVID}

Dalia research in 45 countries in March 2020 found that the Vietnamese surveyed reported the lowest percentage globally asserting that their government had done 'too little' in response to the pandemic (13 percent) and the highest asserting 'the right amount' (62 percent). Reports in May again showed a relatively high level of support for the government and also relatively high levels of consumer confidence.

One way of accessing public opinion is to look at Facebook. Vietnamese colleagues say Facebook was part of a public discussion that was important as people 'made up their minds'.[1] It underpins the poll data from Dalia. In English, official responses to COVID have been vigorously discussed and widely praised, commonly in terms of good results coming from to good policies. Again, it is worth pointing out that these analyses skirt around the complexities of specialist modelling and uncertainties about specific results. Of course, the Vietnamese language sources are far more extensive (social media especially) and show, so far as we know so far, vigorous discussion, praise and criticism of officials' actions and the usual components of a considered popular response (of this, a dozen PhDs could be written (and hopefully will be).

For the population as a whole, policy came out of these vivid discussions as something to be deemed good and so to be authorised. This led to compliance, local modifications and a sharp increase in state capacity. This was both expected and unexpected depending on your views of Vietnamese politics and its core political culture. Thus, I have been told by one Vietnamese 'war is one thing, and then the population looks for strong leadership; when it is a matter of making a living, they want a more democratic politics'. And by another, 'yes, but what will happen at the 2021 XIIIth Party Congress?'. Their point here was the simple one that the longstanding political tensions in Vietnam suggests that the positive lessons of the experience of COVID-19 will need to be seen in their wider context. Put rhetorically, 'if we can cope with COVID-19, why can't we cope with other issues, such as 
corruption?'

Examination of the Facebook pages of various well-known people shows a vivid and open discussion. And there are other sources, such as newspapers, TV and so on. The overall impression gained from this abundant data is that people have formed their own views. One might say 'as ever' and that Mark Zuckerberg's influence is showing more than Karl Marx. (After all, the basic thesis of my own PhD was that, most of the time, members of Vietnamese communist collective farms-the cooperatives-did not do what they were meant to: markets and private production exceeded the norms laid down by the Party, and this before 1975 in the Democratic Republic of Vietnam.)

The Vietnamese have come to have little reason uncritically to trust the ruling Vietnamese Communist Party. There is a long history of popular 'unruliness' and growing willingness to demonstrate and mobilise in other ways against disliked policies. The Party has lost considerable authority, for example: its failure to deal with widespread corruption, suspicions that elements within it may be 'soft on China', a common general sense that it is distant from the people, with increasing violence against opponents. The Vietnam studies literature on this is extensive, with superb recent theses in English by Vietnamese on corruption and the innovations in Đà năng under the late Nguyẽn Ba Thanh. And the state and Party structures do not normally show high levels of internal discipline, so policies on paper are not guaranteed to be implemented. Much of this is due to corruption, where a recent excellent article, again by Vietnamese, reported that Vietnamese businesses on average pay out in bribes about the same amount as they report in profits (yes, that much). Investigations of Party members' possibly corrupt activities by state bodies reportedly cannot procede without formal Party approval, as stipulated by Politburo Directive \# 15 (2007). 


\section{The Vietnamese state has been part of focused and effective national action}

COVID-19 is a virus that poses the experts with considerable technical problems, ranging from understanding or predicting its spread to how to help people who are ill with it. Naturally, there is a need and a drive to 'create meaning', and it is clear already that Vietnam's apparent success is widely attributed to state actions: 'good policy'.

However, this analysis tends to assume that policy is to be judged on whether it is right in cause-effect terms and tends to ignore the issue of whether it is persuasive. This tends also to accept arguments that authoritarian regimes have advantages as they can, relatively speaking, ignore issues of persuasion and so will be successful 'if they adopt correct policies', implying that it is relatively easy to know what policies are correct. There is abundant academic work, and practical experience, suggesting that this is a big ask: political judgements may suggest that ' $\mathrm{X}$ caused $\mathrm{Y}$ ', but for the poor analyst, things are far trickier. What actually happened to social distancing in the different quarters of Đà năng last Tuesday? Why? What do we mean by social distancing in a well-resourced model, where it appears as a vector of even a matrix of variables that are themselves a mixture of sampled data and imposed numbers derived from other contexts?

As such, it combined consensual popular compliance (and so more and better selfpolicing) with sound policies with both societal and leadership pressure upon officials to 'step up'. Popular authorisation, responding to political signals that deployed deep and powerful meanings, therefore increased the power of the state; officials in the public health sector, a sector riddled by corruption, were therefore praised and criticised in ways that worked in Vietnam for the Vietnamese. This has led to success 'so far'.

They stepped up at a time of national emergency. The most persuasive view is that 
authority, conferred upon officials and state actions by the population, based upon informed critical reflection and choice, is key.

These core lessons, of the origins of a national endeavor, are not fully appreciated by the current top Party leadership, which stresses instead the leadership role of the Party and state.

There is, for the Vietnamese, an emerging political opportunity, a 'semi-structured void'. How and if the Vietnamese exploit this will require clever politics, intellectual creativity and, likely, luck. But the importance of political processes in authorising state actions to secure narratives of success that are persuasive (a circular process) and the consequences both political and in terms of coping with COVID-19, is clear from an increasingly wide range of countries, many far richer than Vietnam. And it is also relevant that, were popular confidence in the Vietnamese state's capacity to address COVID-19 in persuasive ways to collapse, the success 'so far' may in a longer time frame prove to have been a short positive interlude in a tragedy.

In the wider frame, Vietnam's experience with COVID-19 'so far' suggests that in general policies are under pressure, and rightly so, to be persuasive as much as to be 'right'. Given the sheer technical difficulties involved in understanding specialists such as epidemiologists, biochemists and their models, is impossible for lay people to understand the notions of causality within these models, especially in the form that 'X will lead to Y, perhaps with uncertainty' of mainstream policy narratives. There is therefore much to be admired in the politics of experts such as Dr Anthony Fauci, the Director of the US National Institute of Allergy and Infectious Diseases, who is almost certainly impossible for lay people to understand when he talks technically with his peers.

The fascinating question for Vietnam, therefore, is whether the lesson (so far) from COVID-19, that 'we can do this' can be extended to other areas, such as corruption. And corruption is widespread in the health services, where as a matter of course people with proper health insurance have to make corrupt payments to secure 
proper service.

As already mentioned, I make a strong distinction between what appears to have led to success in Vietnam, and what epidemiologists' models would show us, because the latter are far more complicated in their causality than simple popular narratives. Premier Phúc's call to avoid 'subjectivity' ('chủ quan') can be taken to be a call for respect for local realities rather than broad ideological generalities, which I see as reflecting Vietnamese tendencies to accept, and play to, local variations in 'mentality' ('tư duy'). This has wider political implications going into the early 2021 Party Congress. By contrast with the Premier's language, on March 31 there is an Appeal from the VCP General-Secretary. Again, the language is 'war in a time of peace' ('cuộc chiến đấu trong thời bình'). But the main thrust is to thank officials for their leadership and the people for their obedience. This I think reflects a profound political difference-does state authority come from a considered and not inevitable series or political acts by the Vietnamese people (as my analysis of COVID-19 suggests), or from the Party itself? In this sense, Vietnam's COVID-19 success is not in the first instance to be credited to the Party, but the people. As the blogger Lưu Trọng Văn put it: 'Thuận lòng Dân, Dân ủng hộ' - roughly, 'if the people appreciate what you do, they will support you'.

[1] Pages mentioned, in what is not intended as an exclusive list, include those of: Lưu trọng Văn; Huỳnh thế Du; A Nguyen Quang; Vu Kim Hanh; Truong Huy San (Huy Duc); Nguyen si dung; Chanh tam; Vinh Dinh Tran; Nguyen Quang Lap; and Đặng Hùng Võ. On Facebook, some Vietnamese give their names with diacritics, some do not.

Related webinar: Governance or social resilience: Learning from Southeast Asia's experience with COVID-19.

Image: Hanoi. Credit: Nam-ho Park/Flickr. 